\title{
Uji daya hambat ekstrak tinta cumi-cumi (Loligo sp) terhadap pertumbuhan bakteri Staphylococcus aureus
}

\author{
${ }^{1}$ Mayangsari P. Rahayu \\ ${ }^{2}$ Damajanty H. C. Pangemanan \\ ${ }^{1}$ Christy N. Mintjelungan
}

\author{
${ }^{1}$ Program Studi Pendidikan Dokter Gigi Fakultas Kedokteran \\ ${ }^{2}$ Bagian Fisiologi Fakultas Kedokteran \\ Universitas Sam Ratulangi Manado \\ Email: mayangrhyu98@gmail.com
}

\begin{abstract}
Mouthwash could inhibit the growth of Staphylococcus aureus bacteria in the oral cavity. Albeit, the most widely used today is mouthwash containing clorhexidine that has side effects in prolonged use. Therefore, it is necessary to find new agents as an alternative antibacterial, especially against Staphylococcus aureus. Squid ink is one of the best known seafood used as alternative medicine which has a wide range of therapeutic applications. This study was aimed to evaluate the inhibitory effect of squid ink extract (Loligo sp) on the growth of $S$. aureus. This was a true experimental study with a post test only control group design. We used modified Kirby-Bauer method using filter papers. Ciprofloxacin antibacterial was used as the positive control and aquadest as the negative control. Extract of squid ink (Loligo sp) and stock of pure bacteria $S$. aureus bacteria were prepared. The results showed that mean of zone of inhibition of the squid ink extract (Loligo sp) was $11.22 \mathrm{~mm}$ which was less than the zone of inhibition of ciprofloxacin. In conclusion, the squid ink extract (Loligo sp) had a moderate inhibitory effect (Himedia category) on the growth of Staphylococcus aureus.
\end{abstract}

Keywords: extract of squid ink (Loligo sp), Staphylococcus aureus, inhibitory effect

\begin{abstract}
Abstrak: Salah satu cara penanganan bakteri Staphylococcus aureus dalam rongga mulut ialah dengan menggunakan obat kumur. Yang banyak digunaakan saat ini yaitu obat kumur yang mengandung clorhexidine dengan efek samping bila digunakan secara berkepanjangan. Oleh karena itudiperlukan penelitian terhadap agen baru sebagai alternatif antibakteri khususnya terhadap bakteri Staphylococcus aureus. Tinta cumi-cumi merupakan salah satu hasil laut yang dikenal dalam dunia pengobatan alternatif serta memiliki jangkauan yang luas pada aplikasi terapeutik. Penelitian ini bertujuan untuk mengetahui daya hambat ekstrak tinta cumi-cumi (Loligo sp) terhadap pertumuhan bakteri $S$. aureus. Jenis penelitian ialah eksperimental murni dengan post test only control group design. Metode yang digunakan yaitu metode modifikasi Kirby-Bauer dengan menggunakan kertas saring. Kontrol positif menggunakan antibakteri siprofloksasin dan kontrol negatif menggunakan akuades. Pada penelitian ini digunakan ekstrak tinta cumi-cumi (Loligo sp) dan stok bakteri murni S. aureus. Hasil penelitian mendapatkan bahwa diameter rerata zona hambat dari ekstrak tinta cumi-cumi (Loligo sp) terhadap pertumbuhan bakteri $S$. aureus sebesar 11,22 $\mathrm{mm}$ namun diameter tersebut lebih kecil daripada diameter zona hambat siprofloksasin. Simpulan penelitian ini ialah ekstrak tinta cumi-cumi (Loligo sp) memiliki daya hambat kategori sedang (Himedia) terhadap pertumbuhan bakteri $S$. aureus.
\end{abstract}

Kata kunci: tinta cumi-cumi (Loligo sp), bakteri Staphylococcus aureus, daya hambat 
Kesehatan gigi dan mulut seringkali bukan menjadi prioritas utama bagi sebagian orang, padahal gigi dan mulut merupakan 'pintu gerbang' masuknya kuman dan bakteri. Kesehatan gigi dan mulut tidak hanya terkait dengan persoalan estetika, tetapi juga dapat menimbulkan masalah kesehatan yang serius apabila kesehatan rongga mulut terabaikan. Dengan demikian, kesehatan gigi dan mulut merupakan bagian dari kesehatan tubuh yang tidak dapat dipisahkan satu dengan lainnya karena akan memengaruhi kesehatan tubuh secara keseluruhan.

Hasil data riset kesehatan dasar (Riskesdas) pada tahun 2018 menunjukkan proporsi masalah penyakit gigi dan mulut di Indonesia sebesar 57,6\%. ${ }^{1}$ Penyakit gigi dan mulut yang sering diderita masyarakat Indonesia yaitu penyakit pulpa dan periapikal, penyakit ini termasuk dalam 10 besar penyakit rawat jalan di Indonesia dengan jumlah kunjungan sebanyak 163.211 kunjungan dalam setahun. ${ }^{2}$

Penyebab utama penyakit periapikal dapat dibedakan menjadi 2 golongan, yaitu living irritants dan non-living irritants. Yang termasuk dalam living irritants ialah mikroorganisme dan virus, sedangkan nonliving irritants ialah iritan mekanis, suhu, dan kimia. Dari kedua penyebab tersebut, lesi pada jaringan periapikal paling sering disebabkan oleh elemen bakteri yang berasal dari sistem saluran akar gigi yang terinfeksi. ${ }^{3}$

Bakteri yang dapat menyebabkan infeksi di rongga mulut salah satunya yaitu bakteri Staphylococcus aureus yang merupakan bakteri Gram positif yang dapat menyebabkan infeksi fasial, periapikal dan denture sore mouth. ${ }^{4}$ Bakteri ini dapat menyebabkan terjadinya nekrosis jaringan setempat yang kemudian disusul dengan pembentukan sel radang sehingga akan terjadi pencairan sel nekrotik berupa abes. ${ }^{5}$

Salah satu cara untuk mencegah infeksi yang disebabkan oleh bakteri $S$. aureus dalam rongga mulut yaitu dengan pemakaian obat kumur. Pemakaian obat kumur bertujuan untuk membunuh bakteri, sebagai penyegar, dan menghilangkan bau tak sedap, serta berefek terapeutik dengan menyembuhkan infeksi. ${ }^{6}$ Obat kumur yang saat ini banyak digunakan yaitu yang mengandung clorhexidine, padahal obat kumur jenis ini memiliki efek samping berupa pewarnaan gigi dan menurunnya daya pengecapan jika digunakan secara berkepanjangan. ${ }^{7}$ Oleh karena itu, diperlukan penelitian terhadap agen baru sebagai alternatif antibakteri khususnya terhadap bakteri $S$. aureus.

Kebutuhan terhadap obat-obatan alternatif dari alam untuk mengatasi infeksi bakteri semakin mendesak dikarenakan kebutuhan obat di Indonesia termasuk ketersediaan obat biologi masih dipenuhi oleh produk impor. Obat biologi sendiri mengandung substansi bioaktif alami yang memiliki efek samping lebih minimal dibanding substansi sintetis sehingga lebih aman bagi tubuh pejamu.

Laut menyediakan produk-produk yang sangat berguna bagi masa depan pengobatan. Salah satu hasil laut yang memiliki khasiat farmasetika yaitu cumicumi, terutama pada tinta yang dihasilkannya. Tinta cumi-cumi terbukti banyak berperan dalam dunia pengobatan alternatif serta memiliki jangkauan yang luas pada aplikasi terapeutik. ${ }^{8}$ Telah diketahui tinta cumi-cumi mengandung melanoprotein yang terdiri dari melanin sebanyak $15 \%$ dari total berat basah tinta dan protein sebanyak 5-8\%. ${ }^{9}$

Sulawesi Utara merupakan salah satu provinsi di Indonesia yang mempunyai sumber daya alam yang berlimpah, termasuk potensi laut, salah satunya yaitu cumicumi. Penelitian sebelumnya oleh Posangi et $\mathrm{al}^{10}$ menggunakan tinta cumi-cumi dan diujikan pada bakteri saluran akar yaitu Streptococcus pyogenes. Hasil penelitian tersebut menunjukkan bahwa tinta cumicumi memiliki efek antibakteri terhadap bakteri tersebut. Berdasarkan latar belakang tersebut peneliti tertarik untuk melakukan penelitian uji daya hambat ekstrak tinta cumi-cumi (Loligo sp) terhadap pertumbuhan bakteri Staphylococcus aureus. 


\section{METODE PENELITIAN}

Penelitian ini merupakan penelitian eksperimental murni (true experimental design) dengan rancangan penelitian post test only control group design. Penelitian dilaksanakan di Laboratorium Farmasi Fakultas MIPA Universitas Sam Ratulangi Manado pada bulan April-Mei 2019. Subjek penelitian yaitu bakteri Staphylococcus aureus. Metode yang digunakan yaitu metode modifikasi Kirby-Bauer dengan menggunakan paper disk. Bakteri $S$. aureus yang disimpan pada media tanam Nutrient Agar (NA) diambil dari stok bakteri murni di Laboratorium Farmasi Fakultas MIPA Universitas Sam Ratulangi Manado.

Bakteri S. aureus diambil dengan jarum ose, lalu diletakkan pada nutrient agar (NA) miring dengan cara menggores. Bakteri diinkubasi dalam inkubator pada suhu $37^{\circ} \mathrm{C}$ selama $1 \times 24$ jam kemudian bakteri tersebut dibuat suspensinya dengan cara melarutkan bakteri dengan larutan $\mathrm{NaCl} \quad 0,9 \%$ sampai kekeruhanya sesuai dengan standar kekeruhan McFarland.

Selanjutnya paper disk pertama dicelupkan ke dalam ekstrak tinta cumicumi (Loligo sp) dengan konsentrasi $100 \%$ kemudian diletakan di atas media MHA yang sudah ditanamkan bakteri. Paper disk kedua kontrol positif yaitu paper disk yang sudah berisi sediaan antibiotik siprofloksasin. Paper disk ketiga dicelupkan ke dalam kontrol negatif yaitu akuades. Setelah itu cawan Petri diinkubasi dalam inkubator dengan suhu $37^{\circ} \mathrm{C}$ selama 1 x 24 jam. Klasifikasi respon zona hambat yang digunakan yaitu: $<4 \mathrm{~mm}$ (tidak ada aktivitas), 5-9 $\mathrm{mm}$ (lemah), 10-14 $\mathrm{mm}$ (sedang), dan $>15 \mathrm{~mm}$ (kuat). ${ }^{11}$ Diameter zona hambat dapat diukur menggunakan rumus:

$$
\frac{D_{v}+D_{h}}{2}
$$

Gambar 1 menunjukkan cara pengukuran diameter zona hambat. ${ }^{12}$

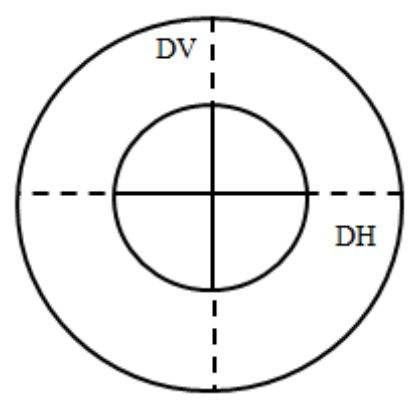

Gambar 1. Pengukuran diameter zona hambat. $\mathrm{D}_{\mathrm{V}}$ :Diameter Vertikal, $\mathrm{D}_{\mathrm{H}}$ :Diameter Horizontal

Tabel 1. Hasil pengukuran rerata diameter zona hambat bakteri Staphylococcus aureus

\begin{tabular}{cccc}
\hline & \multicolumn{3}{c}{ Diameter Zona Hambat (mm) } \\
\cline { 2 - 4 } Pengulangan & $\begin{array}{c}\text { Ekstrak tinta cumi-cumi } \\
\text { (Loligo } \mathrm{sp})\end{array}$ & $\begin{array}{c}\text { Kontrol positif } \\
\text { (Siprofloksasin) }\end{array}$ & $\begin{array}{c}\text { Kontrol negatif } \\
\text { (Akuades) }\end{array}$ \\
\hline 1 & 9,75 & 26,50 & 0 \\
2 & 11,57 & 27,35 & 0 \\
3 & 8,60 & 27,92 & 0 \\
4 & 14,67 & 26,50 & 0 \\
5 & 11,55 & 26,35 & 0 \\
Rerata & 11,22 & 26,92 & 0 \\
\hline
\end{tabular}

\section{BAHASAN}

Penelitian ini merupakan uji eksperimental laboratorium untuk mengetahui adanya efek aktivitas antibakteri dari ekstrak tinta cumi-cumi (Loligo $\mathrm{sp}$ ) terha- dap bakteri $S$. aureus. Penelitian ini dilakukan dengan menggunakan bakteri $S$. aureus yang dibiakkan dalam media tanam berupa Muller-Hinton Agar (MHA). Kontrol negatif yang digunakan ialah 
akuades sedangkan kontrol positif ialah siprofloksasin.

Berdasarkan hasil pengamatan terhadap lima cawan Petri terlihat adanya zona hambat yang terbentuk di sekitar paper disk yang diberi ekstrak tinta cumi-cumi (Loligo $\mathrm{sp})$. Rerata diameter zona hambat yang terbentuk pada ekstrak tinta cumi-cumi (Loligo sp) setelah lima kali pengulangan yaitu $11,22 \mathrm{~mm}$. Rerata diameter zona hambat ini diukur menggunakan skala sensitivitas (Himedia) dan hasilnya termasuk dalam kategori zona hambat sedang.

Hasil dari ketiga paper disk tersebut menunjukkan bahwa paper disk yang berisi ekstrak tinta cumi-cumi (Loligo sp) memiliki diameter lebih kecil dari paper disk yang berisi siprofloksasin, sedangkan paper disk yang berisi akuades tidak menunjukkan adanya zona hambat. Hasil diameter ekstrak tinta cumi-cumi (Loligo sp) yang lebih kecil daripada antibakteri siprofloksasin dapat dipengaruhi oleh konsentrasi hambat minimal antibakteri siprofloksasin yang telah diketahui yaitu 32 $\mu \mathrm{g} / \mu \mathrm{l}$, sedangkan untuk kemampuan ekstrak tinta cumi-cumi (Loligo sp) belum diketahui konsentrasi yang sesuai untuk menghambat bakteri $S$. aureus.

Zona hambat yang terbentuk di sekitar paper disk berisi ekstrak tinta cumi-cumi (Loligo sp) dapat disebabkan oleh kandungan tinta cumi-cumi berupa melanin yang dapat menghambat pertum-buhan bakteri $S$. aureus. Secara umum kandungan tinta cumi-cumi terdiri mela-nin dan protein, juga terdapat tirosin, dopamin dan L-dopa serta sebagian kecil asam amino di antaranya ialah taurin, asam aspartat, asam glutamat, alanin dan lisin. ${ }^{13}$ Melanin dari tinta cumi-cumi mengandung eumelanin alami yang memiliki kemampuan mengabsorpsi logam dengan konsentrasi tinggi pada dinding sel bakteri yang mengandung banyak jenis kation, termasuk $\mathrm{Mg}^{2+}, \mathrm{Ca}^{2+}$, $\mathrm{Na}^{+}$, dan K. Ion-ion ini bertanggung jawab atas berbagai aktivitas bakteri, termasuk kerja enzim, pengaturan metabolik, dan menjaga integritas lapisan luar. ${ }^{14}$

Uji daya hambat dari ekstrak tinta cumi-cumi (Loligo sp) terhadap pertum- buhan bakteri Staphylococcus aureus merupakan penelitian yang belum pernah dilakukan. Beberapa penelitian sebelumnya yang pernah dilakukan yaitu uji daya hambat ekstrak tinta cumi-cumi (Loligo sp) terhadap bakteri penyebab infeksi lainnya beberapa diantaranya yaitu penelitian yang dilakukan oleh Posangi et al ${ }^{10}$ di Manado dengan judul uji efek antibakteri tinta cumi-cumi (Loligo sp) terhadap bakteri saluran akar gigi, bakteri yang digunakan ialah Streptococcus pyogenes. Hasil penelitian mendapatkan bahwa tinta cumi-cumi memiliki efek antibakteri terhadap bakteri Streptococcus pyogenes. Uji daya aktivitas antibakteri dari melanin tinta sotong dan cumi-cumi terhadap bakteri Esherichia coli telah dilaporkan oleh Yuspihana dan Khotimah di Kalimantan Selatan yang menyatakan melanin dari tinta sotong dan cumi-cumi (Loligo sp) memiliki aktivitas penghambatan terhadap bakteri Esherichia coli. $^{15}$ Penelitian lainnya yang dilakukan oleh Kurniawan ${ }^{16}$ di Surabaya mengenai uji efektivitas ekstrak tinta cumi-cumi (Loligo sp) terhadap pertumbuhan bakteri Salmonella typhi menyatakan bahwa ekstrak tinta cumi-cumi (Loligo sp) dapat menghambat pertumbuhan bakteri Salmonella typhi. ${ }^{16}$ Hasil penelitian yang dilakukan oleh Smiline $^{17}$ di Chennai menyarankan penggunaan tinta cumi sebagai produk biofarmasi dengan sifat antibakteri terhadap strain produksi ESBL yang berlaku untuk Escherichia coli and Klebsiella pneumoniae. Selain itu, terdapat juga penelitian mengenai tinta cumi-cumi yang menggunakan beberapa bakteri sekaligus yaitu penelitian oleh Fatimah yang menggunakan bakteri Bacillus subtilis, Eserichia coli, salmonella sp, dan Staphylococcus aureus. Hasil penelitian tersebut mendapatkan bahwa tinta cumi-cumi berpengaruh dalam menghambat pertumbuhan bakteri-bakteri tersebut, dengan zona hambat yang terbentuk yaitu $7-15 \mathrm{~mm}$. $^{18}$

Antibakteri siprofloksasin digunakan sebagai kontrol positif karena di Indonesia siprofloksasin merupakan salah satu antibiotik floroquinolon yang paling banyak digunakan. Floroquinolon termasuk anti- 
biotik berspektrum luas yang digunakan untuk terapi infeksi dan memiliki kepekaan terhadap semua bakteri di antaranya bakteri Gram negatif dan bakteri Gram positif. ${ }^{19}$

Penelitian ini menunjukkan bahwa ekstrak tinta cumi-cumi (Loligo sp) memiliki daya hambat terhadap pertumbuhan bakteri Staphylococcus aureus, namun zona hambatnya lebih kecil dibandingkan dengan antibakteri siprofloksasin. Hal ini menunjukkan adanya senyawa antibakteri dalam ekstrak tinta cumi-cumi tersebut (Loligo sp).

\section{SIMPULAN}

Berdasarkan hasil penelitian ini dapat disimpulkan bahwa ekstrak tinta cumi-cumi (Loligo sp) memiliki daya hambat terhadap bakteri Staphylococcus aureus yang termasuk dalam kategori sedang menurut skala sensitivitas Himedia.

Penelitian lanjut mengenai uji daya hambat kadar minimum ekstrak tinta cumicumi (Loligo sp) terhadap pertumbuhan bakteri Staphylococcus aureus perlu dikembangkan agar Konsentrasi Hambat Minimum (KHM) dapat ditentukan dengan menggunakan metode konsentrasi bertingkat pada ekstrak tinta cumi-cumi (Loligo sp) terhadap pertumbuhan bakteri Staphylococcus aureus. Selain itu, dibutuhkan penelitian lebih lanjut untuk mengeksplorasi kandungan senyawa-senyawa kimia yang berkhasiat dalam ekstrak tinta cumicumi (Loligo sp).

\section{DAFTAR PUSTAKA}

1. Badan Pemelitian dan Pengembangan Kesehatan. Hasil utama Riskesdas 2018. Jakarta: Kementrian Kesehatan RI, 2018; p. 197-214.

2. Badan Penelitian dan Pengembangan Kesehatan. Profil Kesehatan Indonesia 2010. Jakarta: Kementrian Kesehatan RI, 2011; p. 42.

3. Matriani AA, Kamizar, Usman M. Distribusi penyait periapikal berdasarkan etiologi dan klasifikasi di RSKGM Fakultas Kedokteran Gigi di Universitas Indonesia tahun 2009-2013. Jakarta: FKG UI, 2014;5(2):1-15.

4. Komariah, Wulansari N, Harmayanti.
Efektivitas kitosan dengan derajat deasetilasi dan konsentrasi berbeda dalam menghambat pertumbuhan bakteri Gram negatif (Pseudomonas aeruginosa) dan Gram positif (Staphylococcus aureus) rongga mulut. Jakarta: FKG Trisakti; 2013.

5. Syarurachman A, Chatim A, Buku Ajar Mikrobiologi Kedokteran (Edisi revisi). Jakarta: Bina Rupa Aksara, 2010; p. 131-2.

6. National Dental Care. Does mouthwash work?. Australia. 2018. [cited 2019 Feb 17]. Available from: https: //www.national dentalcare.com.au/does-mouthwashwork/.

7. Yuliharsini S. Efek samping penggunaan obat kumur dalam rongga mulut [Skripsi]. Medan: FKG USU; 2008.

8. Hossain MP, Rabeta MS, Husnul. Medicinal and therapeutic properties of chepalopod ink: a short review. J Food Res. 2018;3(3):1-11.

9. Derby C. Cephalopod ink: Production, chemistry, functions and applications. $\mathrm{J}$ Marine Drugs. 2014;12:2700-30.

10. Posangi J, Juliatri, Bara R, Tairas J, Wuisan J. Uji efek antibakteri tinta cumi-cumi (Loligo sp) terhadap bakteri saluran akar gigi. eG. 2013; 1(2):1-6.

11. McGinnis, Ronalde MG, Lorian V, Williams. Antibiotic in Laboratory Medicine (4th ed). Baltimore: Williams \& Wilkins, 1996; p. 177-8

12. Muchyar DSR, Pangemanan DHC, Supit ASR. Uji daya hambat perasan daging buah alpukat (Persea americana Mill.) terhadap pertumbuhan bakteri Staphylcoccus aureus. eG. 2018;6(1):34-8.

13. Agusandi, Supriadi A, Lestari DS. Pengaruh penambahan tinta cumi-cumi (Loligo sp) terhadap kualitas nutrisi dan penerimaan sensoris mi basah. Fishtech. 2013;2(1):22-37.

14. Chen S, Xue C, Wang J, Feng H, Wang Y, Ma Q, Wang D. Absorbtion of $\mathrm{Pb}$ (II) and $\mathrm{Cd}(\mathrm{II})$ by squid ommasthrepes bathrami melanin. Qingdao. China: Ocean University of China. 2009; 2009(2009);1-7.

15. Yuspihana F, Khotimah IK. Aktivitas antibakteri dari melanin tinta sotong dan cumi-cumi. JPHPI. 2017;20(2):266-74.

16. Kurniawan I. Uji efektivitas ekstrak tinta cumi-cumi (Loligo sp) terhadap 
pertumbuhan bakteri Salmonella typhi. Surabaya: FKM Unusa. 2019.

17. Girija S, Priyadharsini V, antibacterial effect of squid ink on ESBL producing strains of Escherichia coli and Klebsiella pneumoniae. Indian Journal of GeoMarine Science. 41(4): 338-43.

18. Zaharah F, Raberta MS. Antioxidant and antimicrobial activities of squid ink powder. Food Research. 2018:2-6. Doi: 10.26656/fr.2017.2(1).225

19. Chudlori B, Kuswandi M, Indrayudha $P$. Pola kuman dan resistensinya terhadap antibiotika dari spesimen pus di RSUD Dr. Moewardi tahun 2012. Pharmacon. 2012;13(2):70-6. 